\title{
Common Ventricle Disorder
}

National Cancer Institute

\section{Source}

National Cancer Institute. Common Ventricle Disorder. NCI Thesaurus. Code C99542.

An umbrella term used to describe several very different complex congenital heart defects that share the same problem: the heart has only one functional ventricle (anatomically right or left or indeterminate) supplying the systemic circulation. These defects include tricuspid atresia, hypoplastic left or right heart syndrome, double outlet right ventricle, double inlet left ventricle, and other forms of single ventricle defects. 